\title{
Analisis Kompetensi Softskill Pada Staff Pengajar Perguruan Tinggi Swasta Di Kota Medan
}

\author{
Dhian Rosalina ${ }^{1}$ \\ Fakultas Ekonomi Universitas Samudra \\ Dhian.rosalina@unsam.ac.id \\ Kartika Yuliari \\ Fakultas Ekonomi Universitas Kadiri \\ kartikay@unik-kediri.ac.id
}

\begin{abstract}
Soft skills are interpersonal and intrapersonal skills that can boost individual performance, including the teaching profession. The purpose of this study was to determine the profile of soft skills held by lecturers as teaching staff in tertiary institutions. This research was conducted in Medan, North Sumatra. The research method used is research with a qualitative descriptive approach. The sampling technique used was purposive sampling with the number of respondents of one hundred and twenty people. The results of this study are the variables forming soft skills such as leadership, communication, effort, ethics have been perceived well by the respondents, and have become daily behavior, although there are a few behaviors that require improvement, such as discipline in the lecture time, while the soft forming variables are skills such as Organizational skills and group skills are perceived to be lacking in teaching and learning activities by the respondents.
\end{abstract}

Key Words : Soft Skill, Qualitative Descriptive Analysis

\begin{abstract}
Abstrak
Soft skill adalah ketrampilan interpersonal dan intrapersonal yang dapat mengembangkan dan memaksimalkan kinerja termasuk profesi dosen. Tujuan dari penelitian ini adalah mengetahui profil softskill yang dimiliki oleh Dosen sebagai staff pengajar di perguruan tinggi. Penelitian ini dilaksanakan di Medan, Sumatera Utara. Metode penelitian yang digunakan adalah penelitian deskriptif kualitatif . Teknik sampling yang digunakan adalah purposive sampling dengan jumlah responden sebesar seratus duapuluh orang. Hasil dari penelitian ini adalah Variabel pembentuk soft skill seperti Leadership, komunikasi, effort, ethics sudah dipersepsikan baik oleh para responden, dan telah menjadi perilaku sehari hari, meskipun ada sedikit perilaku yang memerlukan perbaikan, seperti kedisiplinan terhadap waktu perkuliahan., sedangkan Variabel pembentuk soft skill seperti Organizational skill dan group skill dipersepsikan kurang dilakukan dalam kegiatan belajar mengajar oleh para responden.

Kata Kunci : Soft Skill, Analisis Deskriptif Kualitatif.
\end{abstract}

\section{Latar Belakang}

Indonesia menghadapi persaingan global dalam berbagai bidang, salah satunya adalah persaingan sumber daya manusia. Hal ini dapat dilihat dengan adanya komunitas 
Masyarakat Ekonomi Asean (MEA), yang mengakibatkan konsekuensi semakin ketatnya persaingan dalam dunia kerja, karena Sumber daya manusia dalam negeri bersainga dengan SDM global. Kebutuhan akan tenaga kerja yang terampil mutlak dibutuhkan, tidak hanya hard skill, melainkan juga soft skill. Perguruan tinggi merupakan institusi pendidikan yang berperan dalam menciptakan sumber daya manusia yang kompetitif dalam bidang. Dunia pendidikan dalam konteks ini bebeapa fungsi utama (Neno, 2013) Pertama, kewajiban menyediakan lulusan yang berkualitas dan disiplin yang tinggi, maupun menjadi dinamisator, inovator, motivator penggerak kebudayaan bangsa. Kedua, dunia pendidikan khususnya pendidikan tinggi berkewajiban menyediakan sarjana yang siap kerja dan sekaligus memiliki kemampuan menciptakan lapangan kerja. Undang Undang No 20 tahun 2003 menjelaskan bahwa pendidikan adalah usaha sadar dan terencana untuk mengembangkan potensi peserta didik agar memiliki kekuatan spiritual keagamaan, pengendalian diri, kepribadian, kecerdasan dan akhlak mulia serta ketrampilan yang diperlukan dirinya, masyarakat, bangsa dan bernegara. Berdasarkan rujukan tersebut, negara melegitimasi bahwa pendidikan softskill berperan penting membentuk kepribadian dan karakter sumber daya manusia bangsa.

Dosen sebagai staff pengajar di perguruan tinggi memiliki peran yang krusial dalam membentuk kompetensi mahasiswa tidak hanya terbatas pada bidang keilmuan saja akan tetapi pada softskill anak didik. Menurut Mulyatiningsih (2015) Manajemen kerja yang efektif dan perencanaan kerja yang sukses menuntut adanya kompetensi soft skill dalam jabatan di samping kompetensi teknik atau hard skill. Keterampilan ini tidak hanya terbatas pada dosen tetapi secara umum dituntut oleh semua jenis pekerjaan. McLagan dalam Mulyatiningsih (2015) mengidentifikasi 25 kompetensi yang harus dimiliki oleh dosen dalam 'Models for HRD Practice' Kompetensi tersebut kemudian diklasifikasian menjadi 4 kelompok yaitu kompetensi teknik, kompetensi bisnis, kompetensi interpersonal, dan kompensi intelektual. Dimana kompetensi interpersonal merupakan soft skill.

Siti Hamidah (2011) menemukan 14 soft skills urgen untuk dikembangkan dalam pembelajaran produktif: ekspresi diri/ mengembangkan potensi, menghadapi dan mengelola rasa takut/stress, kemampuan untuk selalu belajar, orientasi pada tujuan/target, pemecahan masalah, disiplin, strategi berfikir, usaha keras mencapai sukses, kreativitas, tanggung jawab, tampil profesional. Muchlas Samani (2009) menemukan urutan 
kompetensi utama yang dibutuhkan industri meliputi: jujur, disiplin, tanggungjawab, kerjasama, memecahkan masalah, dan penguasaan bidang kerja. Dosen yang kompeten berdasarkan data empiris yang telah dilakukan dalam beberapa penelitian adalah dosen professional yang mempunyai karakteristik kepribadian menarik (Mulyatiningsih, 2013) hal ini tidak lain adalah dosen dengan komunikasi yang baik lebih disukai oleh anak didik dan berpengaruh terhadap ketertarikan peserta didik dalam mempelajari mendalam materi yang diajarkan, sehingga dosen harus memiliki soft skill atau ketrampilan interpersonal yang baik agar mampu menyampaikan materi sebaik mungkin kepada mahasiswa.

Penelitian ini dilakukan di Medan, Sumatera Utara. Dimana berdasarkan penelusuran penulis terdapat dua puluh universitas swasta, lima puluh Sekolah Tinggi, Tiga puluh tiga Akademi, sepuluh AMIK, dan Delapan politeknik swasta. Medan merupakan ibukota Sumatera Utara yang menjadi rujukan bagi masyarakat untuk melanjutkan pendidikan tingkat lanjut. Dengan fenomena tersebut, maka mutlak dosen dalam instansi pendidikan harus memiliki soft skill yang baik agar dapat mentransfer ilmu pengetahuan dengan maksimal.

\section{Soft Skill}

Softskill adalah kompetensi interpersonal yang sangat sulit didefinisikan sebab sangat subyektif (Marwanti, 2010), softskill hanya dapat diinterpretasikan melalui observasi perilaku manusia. Menurut Mitchell (2008) softskill adalah cara baru untuk menjelaskan sejumlah kemampuan atau talenta yang terlihat saat individu bekerja di tempat kerja.Menurut Sailah (2008) soft skill adalah ketrampilan interpersonal dan intrapersonal yang dapat mengembangkan dan memaksimalkan kinerja. Berbeda dengan hardskills, softskill bersifat umum dan merupakan ketrampilan humanis yang bisa diasah oleh semua profesi. Soft skills adalah kombinasi perilaku, yang meliputi sikap dan motivasi yang menggerakkan perilaku. (Helmlinger, dalam Hamidah, 2012).

Atribut-atribut Soft skills Menurut Patrick S. O’Brien (1997) dapat dikategorikan ke dalam 6 area. Keenam area tersebut adalah:

\section{Communication Skills}

Communication Skills sebagai salah satu atribut soft skillsdapat diartikan sebagai kemampuan mengekspresikan pendapat atau perasaan secara lisan maupun tertulis dengan jelas dan mudah dipahami orang lain. Kemampuan berkomunikasi dapat dibedakan menjadi duajenis, yaitu: 
a. Komunikasi lisan, komunikasi lisan adalah kemampuan mengekspresikan pendapat atau perasaan secara langsung dan mudah dipahami orang lain. Berdasarkan lawan bicara komunikasi lisan dapat dibagi menjadi:

1. Komunikasi Personal (one on one)

2. Presentasi (Presenting)

3. Diskusi Grup (Group Discussion)

b. Komunikasi tulisan, komunikasi tulisan adalah kemampuan mengekspresikanpendapat atau perasaan dengan bahasa tulis yang jelas dan mudah dipahami orang lain. Terdapat tiga tahapan dalam membuat suatu tulisan yakni:

\section{Mencari informasi}

2.Menulis draft

3.Mengedit dan merevisi

\section{Organization Skills}

Organization skills sebagai salah satu atribut soft skillsdapat diartikan sebagai kemampuan dalam mengorganisasikan atau mengatur waktu dan mengelola semangat dalam bekerja dengan menggunakan sumber daya yang tersedia untuk mencapai tujuan tertentu. Organization skills disini terdiri atas dua komponen sebagai berikut:

a. Manajemen waktu, Manajemen waktu adalah kemampuan menggunakan waktu dengan bijaksana dan konsisten pada jadwal dan batas waktuyang disepakati. Konsep manajemen waktu adalah mengelola pelaksanaankegiatankegiatan sedemikian rupa sehingga dapat selesai dengan kualitas maksimal dan stres yang minimal.

b. Meningkatkan motivasi , Motivasi merupakan keinginan atau kebutuhan dalam diri seseorang yang menggerakkannya untuk melakukan sesuatu untuk memenuhi keinginan tersebut. Motivasi terkait dengan bagaimana seseorang mengelola semangatnya.

\section{Leadership}

Leadership sebagai salah satu atribut soft skills dapat diartikan sebagai kemampuan seseorang untuk mempengaruhi dan mengarahkan orang lain dengan mengerahkan sejumlah sumber daya untuk melaksanakan suatu tugas atau pekerjaan 
sesuai dengan aturan dan memotivasi orang lain agar dapat melakukan yang terbaik. Yang dimaksud kepemimpinan disini adalah kepemimpinan efektif . Berikut ini sejumlah karakteristik yang perlu dimilki untuk menjadi pemimpin efektif:
a. Memiliki visi ke depan
b. Cakap secara teknis
c. Membuat keputusan tepat
d. Berkomunikasi dengan baik
e. Memberikan keteladanan dan contoh
f. Mampu menahan emosi
g. Tahan menghadapi tekanan
h. Bertanggung jawab
i. Cekatan dan penuh inovasi

4. Effort

Effort dapat diartikan sebagai kegiatan dengan mengerahkan tenaga, pikiran, atau sumber daya yang ada dan mau mempelajari hal baru untuk mencapai tujuan dan mampu menghadapi berbagai tekanan. Effort disini terdiri atas dua komponen yaitu:

a. Kemampuan dan kemauan belajar, Yaitu kesediaan untuk menjalani proses belajar, memperbaiki diri dari praktek, menjalankan konsep baru, teknologi baru atau metode baru.

b. Ketahanan menghadapi tekanan yaitu, kemampuan untuk mengatasi stres pada saat menghadapi batas waktu yang mendesak. Ketahanan menanggung stres adalah kemampuan untuk tetap tenang dan sabar ketika menghadapi masalah tanpa terbawa emosi.

\section{Group skills}

Sebagai salah satu atribut soft skills, group skillsdiartikan sebagai kemampuan dalam bekerjasama dengan orang lain dalam sebuah tim dan memiliki interpersonal yang baik dengan sesama anggota tim. Group skills disini terdiri atas dua komponen sebagai berikut:

a. Kerja sama tim adalah kerja sama tim adalah kemampuan dalam bekerjasama dengan orang lain secara efektif dan produktif.

b. Kemampuan Interpersonal kemampuan berkomunikasi secara efektif, dan bisa menjalin hubungan secara harmonis dengan orang lain. Kemampuan ini merupakan kemampuan atau keterampilanmelakukan kontak sosial dengan seluruh individu di dalam kelompok. 


\section{Ethics}

Dalam kaitannya dengan soft skills maka etika berperan penting dalam beberapa atribut soft skills, dua diantaranya yaitu decision making dan management conflict.

a. Decision Making, pengertian decision making disini adalah kemampuan dalam pengambilan keputusan yang berdampak untuk jangka pendek dan jangka panjang dengan tepat waktu atas dasar penilaian yang seksama dan dengan sikap yang etis.

b. Management Conflict adalah kemampuan mengidentifikasi sumber konflik antara dirinya dengan orang lain atau antara orang lain dan mampu menyelesaikan konflik tersebut secara konstruktif dengan penilaian yang seksama sesuai dengan moral dan etika agar tercipta keharmonisan.

\section{SoftSkill dan Kompetensi Dosen}

Softskill berhubungan erat dengan kompetensi dosen, hal ini dapat dilihat dari beberapa pendapat, yakni Houston dalam Neno (2013), menjelaskan bahwa kompetensi dosen kemampuan yang ditampilkan oleh dosen dalam melaksanakan kewajibannya memberikan pelayanan pendidikan kepada masyarakat. Cooper, dalam Neno (2013) membagi empat kompetensi dosen, yaitu (1) mempunyai pengetahuan tentang belajar dan tingkah laku manusia; (2) mempunyai pengetahuan dan menguasai bidang studi yang dibinanya; (3) mempunyai sikap yang tepat tentang diri sendiri, teman sejawat dan bidang studi yang binanya; dan (4) mempunyai keterampilan teknik mengajar. Crasser, dalam Neno (2013), membagi empat hal yang harus dikuasai dosen, yaitu: (1) menguasai bahan pelajaran; (2) kemampuan mendiagnosa tingkah laku siswa; (3) kemampuan melaksanakan proses pengajaran; dan (4) kemampuan mengukur hasil belajar siswa. Selain itu beberapa hasil riset juga menunjukkan hubungan softskill dan kompetensi dosen, yaitu salah satunya Hasil penelitian Gordon (1999) menemukan delapan dari 18 pernyataan kompetensi mengajar efektif dan mempunyai hubungan signifikan dan positif adalah tipe kepribadian. Sikora (1997) melaporkan korelasi signifikan untuk 7 kompetensi mengajar pada tipe kepribadian. Dimensi tipe kepribadian dosen yang mempunyai skor tinggi dalam efektivitas mengajar adalah apakah kehadiran dosen diperlukan atau diinginkan, dan apakah mereka bekerja dengan sekuat tenaga untuk menyelesaikan pekerjaan secara penuh dan tepat waktu. 


\section{Metode Penelitian}

Jenis Penelitian ini adalah penelitian deskriptif kualitatif untuk mengidentifikasi kemampuan softskill yang dimiliki oleh dosen di perguruan tinggi swasta di Kota Medan.

\section{Populasi dan Sampel}

Populasi dalam penelitian ini adalah seluruh dosen yang aktif di universitas swasta Kota Medan. Mengingat keterbatasan peneliti, maka peneliti mengambil sampel dari tiga perguruan tinggi swasta di Kota Medan yang sudah terakreditasi institusi B. Dari tiga Sampel penelitian ini adalah 120 orang dosen. Besarnya sampel yang diambil adalah sebesar 40 orang dosen per perguruan tinggi yang terwakili dari keseluruhan fakultas. Teknik pemilihan sampel menggunakan purposive sampling dengan kriteria sebagai berikut :

1. Masa bekerja dosen tersebut adalah minimal lima tahun

2. Status dosen adalah aktif, sudah ber NIDN, dan tidak sedang studi lanju

\section{Operasional Variabel}

Dalam penelitian ini terdapat enam variabel yang digunakan untuk mengetahui seberapa jauh tingkat softskill dosen, indikator yang digunakan merupakan teori dari O’brien (1997) yang dimodifikasi aatau disesuaikan. Keenam variabel tersebut adalah sebagai berikut:

Tabel 1. Definisi Operasional Variabel

\begin{tabular}{|c|c|c|}
\hline Variabel & Definisi & Indikator \\
\hline Komunikasi & $\begin{array}{l}\text { Kemampuan } \\
\text { mengekspresikan pendapat } \\
\text { atau perasaan secara lisan } \\
\text { maupun tertulis dengan jelas } \\
\text { dan mudah dipahami orang } \\
\text { lain }\end{array}$ & $\begin{array}{l}\text { - Keaktifan melakukan } \\
\text { diskusi dengan } \\
\text { mahasiswa } \\
\text { - Percaya diri } \\
\text { menyampaikaan } \\
\text { pendapat baik lisan } \\
\text { maupun tulisan } \\
\end{array}$ \\
\hline $\begin{array}{l}\text { Organizational skill } \\
\text { Pemecahan masalah dalam } \\
\text { organisasi }\end{array}$ & $\begin{array}{lr}\text { Kemampuan } & \text { dalam } \\
\text { mengorganisasikan atau } \\
\text { mengatur waktu dan } \\
\text { mengelola semangat dalam } \\
\text { bekerja dengan } \\
\text { menggunakan sumber daya }\end{array}$ & $\begin{array}{l}\text { - Kemampuan } \\
\text { mengelola waktu } \\
\text { dalam menyelesaikan } \\
\text { pekerjaaan atau tugas }\end{array}$ \\
\hline
\end{tabular}




\begin{tabular}{|c|c|c|}
\hline Variabel & Definisi & Indikator \\
\hline & $\begin{array}{l}\text { yang tersedia untuk } \\
\text { mencapai tujuan tertentu }\end{array}$ & $\begin{array}{l}\text { - Motivasi dalam } \\
\text { penyelesaian tugas }\end{array}$ \\
\hline $\begin{array}{l}\text { Leadership } \\
\text { Tanggung jawab }\end{array}$ & $\begin{array}{l}\text { Kemampuan seseorang } \\
\text { untuk mempengaruhi dan } \\
\text { mengarahkan orang lain } \\
\text { dengan mengerahkan } \\
\text { sejumlah sumber daya untuk } \\
\text { melaksanakan suatu tugas } \\
\text { atau pekerjaan }\end{array}$ & $\begin{array}{l}\text { - Keberanian } \\
\text { mengambil } \\
\text { keputusan } \\
\text { - Mampu mengelola } \\
\text { emosi dan tahan } \\
\text { terhadap tekanan } \\
\text { - Mampu Memotivasi } \\
\text { mahasiswa } \\
\text { - Tanggung jawab } \\
\text { penyelesaian } \\
\text { pekerjaan }\end{array}$ \\
\hline $\begin{array}{l}\text { Effort } \\
\text { Selalu belajar }\end{array}$ & $\begin{array}{l}\text { Kegiatan } \\
\text { mengerahkan } \\
\text { pikiran, atau sumber daya } \\
\text { yang ada dan mau } \\
\text { mempelajari hal baru }\end{array}$ & $\begin{array}{l}\text { - Kemauan untuk terus } \\
\text { belajar } \\
\text { - Kemauan untuk } \\
\text { memperbaiki kualitas } \\
\text { diri } \\
\text { - Tidak mengulangi } \\
\text { kesalahan yang sama }\end{array}$ \\
\hline $\begin{array}{l}\text { Groupskill } \\
\text { Kerjasama }\end{array}$ & $\begin{array}{l}\text { Kemampuan dalam } \\
\text { bekerjasama dengan orang } \\
\text { lain dalam sebuah tim }\end{array}$ & $\begin{array}{l}\text { - Menguasai pekerjaan } \\
\text { dalam kelompok, } \\
\text { - Dapat bekerja sama } \\
\text { dengan siapa saja, } \\
\text { - Memahami posisi } \\
\text { saya dalam kerja tim, } \\
\text { - Tidak kesulitan } \\
\text { mensupport tim }\end{array}$ \\
\hline $\begin{array}{l}\text { Ethics } \\
\text { Kedisiplinan }\end{array}$ & $\begin{array}{l}\text { Tindakan etis baik dalam } \\
\text { pengambilan keputusan } \\
\text { maupun penyelesaian } \\
\text { konflik atau permasalahan, } \\
\text { serta bentuk ketaatan pada } \\
\text { perintah, tata aturan ataupun } \\
\text { petunjuk kerja yang telah } \\
\text { disepakati }\end{array}$ & $\begin{array}{l}\text { - Sikap disiplin dan } \\
\text { adil dalam } \\
\text { memperlakukan } \\
\text { peserta didik } \\
\text { - Datang tepat waktu, } \\
\text { - Menjaga kebersihan } \\
\text { dan ketertiban } \\
\text { lingkungan kerja }\end{array}$ \\
\hline
\end{tabular}

\section{Teknik Analisis}

Data di analisis dengan pendekatan deskriptif kuantitatif dengan klasifikasi, sesuai ketentuan yang menggambarkan sejauh mana atau sekuat dan selemah apa softskills yang dimiliki oleh dosen. Profil softskill terbagi menjadi tiga kategori : kuat, sedang, lemah dengan pemaparan sebagai berikut : 
Tabel 2. Instrumen Pengukuran Softskill Responden

\begin{tabular}{|l|l|c|}
\hline \multicolumn{1}{|c|}{ Opsi } & \multicolumn{1}{|c|}{ Definisi } & Profil Softskill \\
\hline Tidak seperti saya & $\begin{array}{l}\text { Menggambarkan bahwa } \\
\text { penguasaan softskill belum } \\
\text { atau sedikit terdeskripsikan }\end{array}$ & Kurang \\
\hline Kadang - kadang seperti saya & $\begin{array}{l}\text { Menggambarkan bahwa } \\
\text { penguasaan softskill masih } \\
\text { labil atau belum mantap }\end{array}$ & Baik \\
\hline $\begin{array}{l}\text { Selalu atau sering saya } \\
\text { lakukan }\end{array}$ & $\begin{array}{l}\text { Menggambarkan bahwa } \\
\text { penguasaan softskill yang } \\
\text { dideskripsikan sudah menjadi } \\
\text { perilaku sehari hari }\end{array}$ \\
\hline
\end{tabular}

Profil softskill menggambarkan bagaimana dosen mendeskripsikan softskill dalam aktivitas sehari - hari.

\section{Hasil}

Gambaran profil soft skill adalah dalam uraian sebagai berikut:

a. Komunikasi

Kemampuan komunikasi menunjuk pada kemampuan dosen dalam menyampaikan informasi kepada peserta didik, menerima atau menangkap pesan baik saat pembelajaran di kelas ataupun saat diluar kelas. Perilaku pendukung komunikasi antara lain : mudah menjelaskan dan menguraikan materi, mudah menulis naskah atau tugas, mudah menangkap maksud dan pembicaraan, menjadi pendengar yang baik, bicara sesuai dengan topik materi. Dari hasil pengolahan data kekuatan tertinggi adalah: mudah menyusun materi naskah dan tugas (70,43\%), kemudian mudah menjelaaskan dan menguraikan materi $(57,21 \%)$, bicara sesuai dengan topik materi $(42,66 \%)$, mudah menangkap maksud dan pembicaraan $(33,42 \%)$ dan menjadi pendengar baik $(31,75 \%)$. Dari hasil analisis tersebut, dosen lebih menyukai interaksi pasif yaitu menyusun materi perkuliahan seperti menulis bahan dan tugas, dan dalam interaksi aktif seperti kemudahan menjelaskan materi tidak menjadi perilaku utama sehari hari. Urutan terakhir adalah menjadi pendengar yang baik, disini dosen memiliki persepsi bahwa menjadi pendengar yang baik dalam kegiatan pengajaran bukan menjadi prioritas. 


\section{b. Leadership}

Leadership menunjuk pada kemampuan seseorang untuk mempengaruhi dan mengarahkan orang lain dengan mengerahkan sejumlah sumber daya untuk melaksanakan suatu tugas atau pekerjaan Berdasarkan hal tersebut maka ada empat perilaku soft skills yang mencerminkan kriteria tanggung jawab: Keberanian mengambil keputusan, mampu mengelola emosi dan tahan terhadap tekanan, mampu memotivasi mahasiswa, tanggung jawab penyelesaian pekerjaan Hasil analisis menujukkan bahwa kekuatan tertinggi: mampu memotivasi mahasiswa $(74,65 \%)$ dan tanggung jawab dalam penyelesaian pekerjaan (73,24\%). Kekuatan dibawahnya: mampu mengelola emosi dan tahan terhadap tekanan $(69,01 \%)$ serta keberanian mengambil keputusan $(66,20 \%)$.

Berdasarkan paparan di atas maka dapat dinyatakan bahwa sebagian besar dosen berpersepsi bahwa dosen telah memahami dan melaksanakan soft skill leadership, yaitu mampu memotivasi mahasiswa dalam kegiatan perkuliahan, dan secara moral berkomitmen menyelesaikan pekerjaan yang berhubungan dalam kegiatan perkuliahan dengan tanggung jawab.

c. Organizational Skill

Organizational skill diasosiakan dengan pemecahan masalah, yaitu kemampuan dalam mengorganisasikan atau mengatur waktu dan mengelola semangat dalam bekerja dengan menggunakan sumber daya yang tersedia untuk mencapai tujuan tertentu Berdasarkan hal tersebut maka ada dua perilaku soft skills organizational skill : Kemampuan mengelola waktu dalam menyelesaikan pekerjaaan atau tugas dan Motivasi dalam penyelesaian tugas. Berdasarkan kriteria yang ditetapkan maka kekuatan tertinggi adalah motivasi dalam penyelesaian tugas $(67,61 \%)$, diikuti kemampuan mengelola waktu dalam penyelesaian tugas $(56,62 \%)$. Dari hasil analisis tersebut, dosen kurang memiliki soft skill dalam penyelesaian tugas keluhan yang muncul antara lain kesulitan memenuhi tatap muka, materi yang padat, dan lain sebagainya.

\section{d. Group Skill}

Group skill adalah Kemampuan dalam bekerjasama dengan orang lain dalam sebuah tim. Perilaku yang membentuk group skill adalah: Menguasai pekerjaan dalam kelompok, dapat bekerja sama dengan siapa saja, memahami posisi dalam 
kerja tim, tidak kesulitan mensupport tim. Berdasarkan dari hasil analisis data, diperoleh kekuatan tertinggi group skill adalah: Tidak kesulitan dalam mensupport tim $73,24 \%$, diikuti menguasai pekerjaan dalam kelompok 56,62\%, dapat bekerja dengan siapa saja dan memahami posisi dalam tim (50,70\%). Melihat keadaan tersebut maka kemandirian kerja dosen sebagai anggota tim belum terbentuk dengan baik, dosen cenderung bersikap pasif dengan meilihat rendahnya skor partisipasi dalam tim.

e. Ethics

Etika merujuk pada bentuk Disiplin merupakan tindakan etis baik dalam pengambilan keputusan maupun penyelesaian konflik atau permasalahan, dan bentuk ketaatan pada perintah, tata aturan ataupun petunjuk kerja yang telah disepakati. Perilaku yang membentuk ethics adalah : Sikap disiplin dan adil dalam memperlakukan peserta didik, datang tepat waktu, menjaga kebersihan dan ketertiban lingkungan kerja. Berdasarkan kriteria maka kekuatan tertinggi: sikap disiplin dan adil dalam memperlakukan peserta didik (70,42\%). Diikuti dengan partisipasi menjaga kebersihan (69,01\%), dan datang tepat waktu (49,30\%). Dosen memiliki soft skill yang baik dalam hal ethics namun kurang baik dalam memenuhi kedisplinan waktu seperti kesesuaian jam mengajar, keterlambatan masuk perkuliahan.

f. Efforts

Efforts adalah Kegiatan dengan mengerahkan tenaga, pikiran, atau sumber daya yang ada dan mau mempelajari hal baru. Berdasarkan hal tersebut maka ada tiga perilaku soft skills yang membentuk efforts: Kemauan untuk terus belajar, Kemauan untuk memperbaiki kualitas diri, Tidak mengulangi kesalahan yang sama.

Hasil analisis menunjukkan bahwa kekuatan tertinggi dimulai dari : tidak mengulangi kesalahan yang sama $(78,87 \%)$, dan memperbaiki kualitas diri $(73,24 \%)$, terakhir kemauan untuk terus belajar $(60,56 \%)$

Perilaku kemauan untuk terus belajar yang diasosiasikan dengan kemauan untuk studi lanjut cukup rendah, hal ini diketahui dari hasil penelusuran peneliti bahwa faktor faktor seperti biaya yang tinggi, keterbatasan perguruan tinggi yang menyediakan program doktor, menyebabkan rendahnya perilaku tersebut. 


\section{Kesimpulan}

1. Pada umumnya variabel pembentuk soft skill seperti Leadership, komunikasi, effort, ethics sudah dipersepsikan baik oleh para responden, dan telah menjadi perilaku sehari hari, meskipun ada sedikit perilaku yang memerlukan perbaikan, seperti kedisiplinan terhadap waktu perkuliahan.

2. Variabel pembentuk soft skill seperti Organizational skill dan group skill dipersepsikan kurang dilakukan dalam kegiatan belajar mengajar oleh para responden. Hal tersebut dapat dilihat bahwa pada kedua variabel tersebut responden lebih menyukai perilaku yang sifatnya pasif atau tidak partisipatif.

\section{Daftar Pustaka}

Hamidah, Siti. 2012. Profil Softskill Mahasiswa Pendidikan Teknik Boga Fakulttas Teknik Universitas Negeri Yogyakarta.Jurnal Pendidikan Vokasi. Vol2, No.2 Juni 2012

Helmlinger, W. (tth). Do you employee possess the right competencies? Diambil pada tanggal 26 April 2007 dari http://hiring.inc.com/columns.html

Listyani, E. 2011. Pengembangan Softskills Mahasiswa Calon Guru Melalui Perkuliahan di Jurusan Pendidikan Matematika.

Listyani, E. 2011. Pengembangan Softskills Mahasiswa Calon Guru Melalui Perkuliahan di Jurusan Pendidikan Matematika.

Neno, Shinta. 2013. Analisis Kompetensi dan Profesional Dosen.

Muchlas Samani, (2009). Bahan Perkuliahan Program Doktor Pascasarjana UNY

Mulyatiningsih, Endang. 2015. Softskill Sebagai Pendukung Kompetensi Dosen di masa Depan. http://staffnew.uny.ac.id/upload/131808329/penelitian

Mitchell, W.G. (2008). Essential Soft Skills for Success in the Twenty-first Century Workforceas Perceived by

Business Educators. Diambil 8 Mei 2011,dari

etd.auburn.edu/etd/bitstream/handle/ 10415/1441 /mitchell-

Geana_57.pdf? sequene

Marwanti, 2011. Studi Tentang Softskill dan Kesiapan Kerja Sebagai Tenaga Kerja Profesional di Bidang Bogaa Mahasiswa Pendidikan Tata Boga Jurusan Pendidikan Kesejahteraan Keluarga

O'Brien, PS. 1997. Making College Count: A real World Look at How to succeed In and After College. USA: Graphic Management Corp. 
EkoNiKa | Vol. 4, No. 2, September 2019: 167-179

Doi : http://dx.doi.org/10.30737/ekonika.v4i2.435
Analisis Kompetensi .. (Rosalina \& Yuliari)

$P-I S S N: \underline{2502-9304}$

E-ISSN : 2581-2157

Undang Undang No 20 Tahun 2003 tentang Sistem Pendidikan Nasional. 